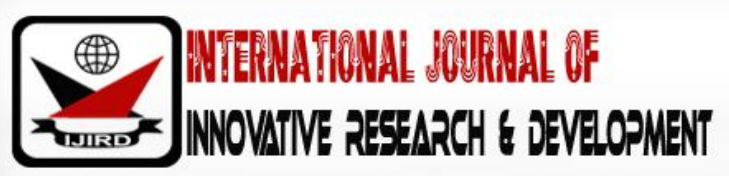

ISSN 2278 - 0211 (Online)

\section{Evaluating the Imperative of Auditing in Situating Good Corporate Governance in Developing Economies: The Nigerian Experience}

\author{
E.A. Udu \\ Lecturer, Ebonyi State University, Nigeria \\ J.N. Eseni \\ Legal Adviser, Federal Teaching Hospital, Nigeria \\ C.V. Iteshi \\ Lecturer, Ebonyi State University, Nigeria
}

\begin{abstract}
:
Auditing is one of the mechanisms adopted for effective corporate governance regime. There is often the need to have an independent body of persons who are to verify the records of stewardship prepared and recorded by those in fiduciary capacity to resource owners. Such reports which show the impact of management's decision on the worth of shareholder's wealth will lack creditability if not verified by an independent expert. This paper is aimed at evaluating the imperative of auditing in situating good governance in corporate businesses. The methodology adopted in this work is doctrinal anchored on appraisal and analysis. It was found that there is façade of corporate auditing as shareholders merely rubber stamp the financial statements presented to them sometimes assuming that the financial statements presented, having gone through internal audit controls, ought to be in order. It was further found that no matter how strict and consistent the rules of auditing are applied, it can hardly afford perfect protection against human factors such as susceptibility to errors, collusion and deceit. It is therefore recommended that the powers of corporate regulators or supervisory agencies should be strengthened and enhanced to include the power to ensure that auditors properly scrutinize the financial statement of the company since adequate accountability may not be achieved through a formalistic observance of the rules of financial reporting and auditing. This should be complemented by the activeness of the shareholders in ensuring good corporate governance. It is the place of the shareholders to consider and approve the appointment and remuneration of auditors as well as the financial statement in a general meeting so as to ensure that the board of directors observes financial discipline in the management of the company.
\end{abstract}

Keywords: External, Auditing, Independence, corporate, imperative, governance

\section{Introduction}

There is always an independent body of persons who are to verify the records of stewardship prepared and recorded by those in fiduciary capacities to resources owners. ${ }^{1}$ Such reports which show the impact of management's decision on the growth of shareholders wealth will lack credibility if not verified by an independent expert. These independent bodies are: the internal auditors, external auditors and audit committee. Accordingly, every company shall at each annual general meeting appoint an auditor or auditors to audit the financial statements of the company and to hold office from the conclusion of that, until the conclusion of the next annual general meeting.'It shall be the auditors' duty to consider whether the information given in the directors' report for the year for which the accounts are prepared is consistent with those accounts and if they are of the opinion that it is not, they shall state that fact in their report. ${ }^{3 T h e}$ audit system has, as its main objective the facilitation of detection of errors or fraud. The audit is an integral element of corporate governance and is carried out by an auditor who reports to the chief executive officer or managing director, and is supposed to assist the executive management and the board in the discharge of their obligations relating to safeguarding asset, risk management, operation of adequate controls and

1Section 279 of CAMA provides that a director of a company stands in a fiduciary relationship towards the company.

${ }^{2}$ Companies and Allied Matters Act (CAMA), Cap. C20, Laws of the Federation of Nigeria 2004, S.357.

${ }^{3}$ Companies and Allied Matters Act, op. cit, S.360 (5). 
reliability of financial statements and stewardship reporting. ${ }^{4}$ This paper will evaluate the imperative of auditing in ensuring good governance regime in corporate businesses.

\section{Imperative of External Auditing in Corporate Governance}

Internal auditing is not always enough to guarantee error free financial statement, and the realization of possible collusion between the executive management and the internal auditor made the provision for external auditor an essential factor for more transparency in the accounting system of company. According to section 358 and 359 of Nigerian Companies and Allied Matters Act (CAMA), chartered accountants, as external auditors are the professional experts empowered to examine these financial statements not only to determine whether they represent a true and fair view of the state of affair of the entity and are free from any material misstatement but also to ascertain whether they conform to the generally accepted accounting principles and other relevant legislations and standards - whether there are errors, misstatement or fraud in the account. ${ }^{5}$

The main objective of external audit is to give a report on the view presented by the financial statements prepared by the managers. The detection of fraud and errors are incidental to this main objective. ${ }^{6}$ External auditors are usually appointed by shareholders and are required to submit their report to shareholders during annual general meeting. This means that external auditors are accountable to the body of shareholders. Nevertheless, subject to section 357(5)(a)\&(b) of CAMA, the first auditors of a company may be appointed by the directors at any time before the company is entitled to commence business and auditor so appointed shall hold office until the conclusion of the next annual general meeting.7 With respect to banks in Nigeria, the appointment of external auditors by the shareholders of a bank is expected to receive the approval of Central Bank of Nigeria (CBN) in line with section 29 of Banks and Other Financial Institutions Act (BOFIA).The report of such external auditors are expected to be read together with the report of the board of directors at the Annual General Meeting while two copies of each report together with the auditor's analysis of bad and doubtful advance in a form specified by the Central Bank of Nigeria shall be sent to the apex bank for its information and consideration. The external auditor is also expected to submit two copies of the management or domestic report to the CBN within 3 months of the end of the financial year of the bank. ${ }^{8}$

The external auditor is an audit professional who performs an audit in accordance with specific laws or rules on the financial statements of a company, government entity, other legal entities or organizations, and who is independent of the entity being audited. Users of these entities financial information such as investors, government agencies, and the general public, rely on the external auditor to present an unbiased and independent audit report. The responsibility of an external auditor is to make sure that there is nothing bad or wrong going on within a company financially. More so, he is engaged to consider an opinion on whether a company's financial statements are presented fairly in all material respects, in accordance with financial reporting framework. An audit conducted in accordance with GAAS and relevant ethical requirements enables the auditor to form the opinion, thus, the auditor gathers appropriate and sufficient evidence and observations that compares and confirms the opinion with reasonable assurance. The auditor then forms an opinion of whether the financial statements are free of material misstatement, either due to fraud or error. The emphasis is on 'independence'. First and foremost, auditor does not take responsibility for the financial statements on which they form an opinion. The responsibility for financial statement presentation lies squarely in the hands of the company being audited. Thus, auditors are not a part of management which means that the auditor will not:

- Authorize, execute or consummate information on behalf of a client

- $\quad$ Prepare or make changes to source documents.

- Assume custody of client assets, including maintenance of bank accounts.

- Establish or maintain internal controls, including the performance of ongoing monitoring activities for a client

- Supervise client employees performing normal recurring activities

- Report to the board of directors on behalf of management

- Serves as a client's stock or escrow agent ${ }^{9}$ or general counsel

- Sign payroll tax returns on behalf of a client

- Approve vender invoices for payment

- Design a client's financial management system or make modification to source code underlying that system

- Fires or terminate employees

\footnotetext{
4Okeahalam, C.C. and Akinbode, O.A., 'A Review of Corporate, Governance in Africa: Literature, Issues and Challenges', a Paper Prepared for the Global Corporate Governance Forum, 15 June, 2003.

5Okpeahior, R. and Faga, H.P. 'Reflection on Sound Corporate Governance for a Thriving National Economic Environment', Ebonyi State University Law Journal, Vol.2, No 1, (2007) p. 218.

6Okeahalam, C.C. and Akinbode, O.A.op. cit, note 4, p.15.

${ }^{7}$ See generally section. 357 of CAMA particularly, subsection 3 of same section which provides that where at an annual general meeting, no auditors are appointed or re-appointed, the directors may appoint a person to fill the vacancy.

${ }^{8}$ Opeahior, R. and Faga, H.P.op. cit, note 5, p.218.

${ }_{9}^{9}$ Escrow is a bond, deed, or other document kept in the custody of a third party and taking effect only when a specified condition has been fulfilled.
} 
On the while, the external auditor evaluates whether audit evidence raises doubt about the ability of the client to continue as a going concern in the passable future. He expresses his assurance on the financial statements in an auditor's report. Further, he has the responsibility to express an opinion on whether management has fairly presented the information in the financial statements. Accordingly by sections 358 and 359 of the Companies and Allied Matters Act, ${ }^{10}$ chartered accountants, as external auditors, are the professional experts empowered to examine these financial statements not only to determine whether they in any way represent a true and fair view of the state of things or business of the company and are also free of any material misstatement but also to ascertain whether they conform to the generally accepted accounting principles and other relevant laws and standards -whether there are errors, misstatements or fraud in the accounts. ${ }^{11}$

It is the responsibility of the Annual General Meeting of a company to appoint external auditors who will be required to submit their reports to them. ${ }^{12}$ By necessary implications, these external auditors are accountable to the body of shareholders but the reverse was the case in the Enron's crisis which showed evidence of misleading accounts, shoddy auditing, and bad management and quite probably an outright fraud. Although Enron is not a financial institution, it was a Houston-based energy firm, founded by Kenneth Life Span from an obscure gas pipeline concern to the World's largest energy trading company. Encouraged by deregulation, the company turned to electricity to supply its natural gas business. Its attempted entry into California's retail electricity market in 2001 was unsuccessful. In the same year, the company's decadelong involvement in DAHOL and India power plant project also ran into deep waters. Lack of transparency undermined Enron's credibility and in October 2001, its shares and credit rating plummeted considerably. In November 2001, a rival firm, backed out of a proposed life line merger after Enron's debt was downgraded to junk status filed for bankruptcy in December 2001. The involvement of a reputable accounting firm like Anderson in shredding of incriminating document just ahead of investigation was very unprofessional. 13

In certain exceptional 'cases, however, the board of directors can appoint external auditors, if the shareholders failed to do so at the Annual General Meeting and such appointment must be communicated to the Corporate Affairs Commission within one week of exercising that power under section 357 (3) of Companies and Allied Matters Acts. ${ }^{14}$ In the case of banks, the appointment of external auditors by shareholders of bank is, however expected to receive the approval of the Central Bank of Nigeria (CBN) in line with section 29 of Banks and other Financial Institutions Act.15 The reports of such external auditors are expected to be read together with the report of the board of directors at the Annual General Meeting -while two copies of each report together with the auditor's analysis of bad and doubtful advances in a form as stipulated by the CBN shall be forwarded to the apex bank for its information and consideration. The external auditor is also expected to submit two copies of the management or domestic report to CBN within 3 months of the end of financial year of the bank. ${ }^{16}$ The external auditor is an independent person or firm of auditors appointed by the shareholders to investigate the financial statements prepared by the management and report its findings to the shareholders. The internal auditors are the employees of a company who are appointed by the management to carry out audit of the day-to-day affairs of the company as part of the internal control system. ${ }^{17}$ But, unlike the internal auditor, the external auditor also is an independent person or firm of auditors appointed according to statutory requirement(s) to investigate the financial statements of an entity and express his opinion in form of report on the true and fair view of such financial statements. ${ }^{18}$

Accordingly, in relation to the external auditors' roles and duties, section 360 (1) - (5) of the Companies and Allied Matters Act ${ }^{19}$ provides that it shall be the duty of the company's auditors, in preparing their report, to carry out such investigations as may enable them to form an opinion as to the following matters whether -

- Proper accounting records have been kept by the company and proper returns adequate for their audit have been received from branches not visited by them;

- The company's balance sheet and (if not consolidated) its profit and loss account are in agreement with the accounting records and returns.

Subsection (2) of same section provide that if the auditors are of opinion that proper accounting records have not been received from branches not visited by them, or if the balance sheet and (if not consolidated) the profit and loss account are not in agreement with the accounting records and returns, the auditors shall state that fact in their report. Also, subsection (3) provides that every auditor of a company shall have a right to access at all times the company's books, accounts and vouchers, and entitled to require from the company's office such information and explanations as he thinks necessary for the

\footnotetext{
10 Cap. C20 LFN, 2004.

${ }^{11}$ Asein, A.A., 'Managing Audit Risks', The Nigerian Accountant, Vol. 32 No 1 (January and March, 1999) (Cited in Okpeahior, R. \& Faga, H.P.,op. cit, note 5, p. 1.

12 Companies and Allied Matters Act, op. cit, section 357.

${ }^{13}$ Onwuoduoki, E.A., 'Current World Financial Crisis: Lessons to be Learnt, in O. Alo (ed), Issues in Corporate Governance, (2003) p. 51, cited in Okpeahior, R. \& Faga, H.P.,op. cit, note 5, pp. 217-218.

14Ibid.,note 13

15 Cap. B3, LFN, 2004.

${ }^{16}$ Banks and Other Financial Institutions Act, Cap. B3, LFN, 2004, S. 29.

17 Alabede, K.O., The Role, Compromise and Problems of the External Auditor in Corporate Governance', Research Journal of Finance and Accounting, Vol. 3 No 9 (2012) p. 115,available at: URL www.iiste.org, accessed on 21/09/13; Aguolu, O.,Fundamentals of Auditing, 3rd edn, (Institute for Development Studies, Nigeria, 2008) p. 7.

18Ibid.

${ }^{19}$ Cap. C20 LFN, 2004; See also the equivalent provisions in the United Kingdom Companies Act 2006, particularly sections 495-498.
} 
performance of the auditor's duties. Also, if the requirements of Part V and VI of Schedule 3 and Part I-III of Schedule 4 to this Act are not complied with in the accounts, it shall be the auditors' duty to include in their report, so far as they are reasonably able to do so, a statement giving the auditors' duty to consider whether the information given in the director's report for the year for which the accounts are prepared is consistent with those accounts; and if they are of opinion that it is not, they shall state that fact in their report. In the case of Leads Estate Building and Investment Co. v Shepherd, ${ }^{20}$ the court stated that it is the duty of the auditor not to confine himself merely to mechanical audit. Although they had not checked the articles of association, they must have known of their existence because every company was required to have articles. In Henry Squire $v$ Ball Baker, ${ }^{21}$ the auditors are expected to go beyond the books and records of the client for evidence to support their opinion about the truth and fairness of the financial statement. Following the case of AWA v Daniels (Trading as Deloitte Haskins \& Sells) $\&$ others, ${ }^{22}$ the court stated that Deloitte failed to perform their contractual duties in three ways:

- It was clear that the books and records relevant to AWA's foreign exchange transactions were inaccurate and inadequate and the auditors should have formed the opinion that accounting records had not been kept.

- The auditors had doubts about the extent of the foreign exchange manager's authority to enter into foreign exchange transactions on behalf of AWA. The auditor had a duty to make enquiries from an appropriate level of management.

- The auditors had discussed the inadequate system of recording foreign exchange transactions with the recording manager of AWA, but they did nothing to ensure that the matter was dealt with urgently and effectively, neither did they ensure that it was referred to AWA's board of directors.

The auditors had been negligent in the performance of their duties and their negligence had contributed to the loss suffered by AWA. AWA's senior management was also found to have contributed to the company's loss by virtue of deficiencies in its system of internal controls and record keeping.

The role of the external auditor is also extended to ascertain and to test the company's financial statement of accounts. An external auditor tests a financial statement item to verify that an account balance is correct and agrees with ledger amounts. A ledger is an accounting record. ${ }^{23}$ For instance, an auditor might review a company's customer accounts to ensure that individual customer balances agree with total accounts receivable. In addition, an external auditor checks the company's accounts and reports to the company based on its findings on such accounts. Thus, in Re London \& General Bank, ${ }^{24}$ the court stated that the auditor's business is to ascertain and state the true financial position of the company during audit. The auditor should examine the books of the company and enquire and take a reasonable care to ascertain that the books of the company show its true position.

The external auditor must ensure that the board of directors and the management are acting responsibly towards the shareholder's investment interest. By keeping objectivity, the external auditors can add value to shareholders by ensuring that the company's internal controls are strong and effective. And by working with the audit committee and liaising with internal auditors, external auditors can help to facilitate a more effective oversight of the financial reporting process by the board of directors. The external auditor also observes the system and management in the company, especially as it relates to its financial statement in the company and if it discovers that the system is weak, that suggests that it is less reliable. In this case, the auditor may have to do more substantive tests in his work and role. Auditor is expected to inform the management about any weakness he observes in the system of its financial statement. It should be noted that weakness in the internal control system in the company makes the work of auditor more difficulty. Empirically, Krishaman and Visvanathan ${ }^{25}$ show that companies with weak internal control system witnessed more auditor changes. The consequence of weak internal control was manifested in the case of Baring Bank in which the General Manager (Leason) to Singapore Office engaged in an authorized speculative trading on the Nikkei, which resulted to loss of E827 million which was without head knowledge of the management at head office in London. ${ }^{26}$

An external auditor reviewing a business entity's processes and final statements learns about the entity's operating environment prior to starting an audit. This involves external and internal factors affecting how the company operates. In other words, this role is referred to as a good understanding of the entity's environment. External factors could include industry practices, regulatory guidelines and business trends. Internal factors might be top management's ethical rules and leadership style, corporate policies and departmental rules. An external auditor analyses financial reporting risks and discusses risks with management. An external auditor reviews internal controls and processes around financial reporting mechanisms to ensure that such mechanism report complete and accurate financial statements. An audit specialist also verifies that a company's records agree with generally accepted accounting principles. And completeness in reporting includes certain types of data sets such as balance sheet, a statement of profit and loss, a statement of cash flows and a statement of shareholders' equity.

20 (1887) 36 Ch. D 787.

21 (1911) 44 Acct LR 25, See also Re City Equitable Fire Insurance Co. Ltd (1924) 71 Acct LR 81.

22 (1992) 10 ACLC 933.

23Available at: http:// www.eh ow.com/ list-6582612-external-auditor-s-duries-html., accessed on 24/ 03/ 2018

24 (1895) 2 Ch. 673

25 Krishaman, G.V. and Visvanathan, G., 'Reporting Internal Control Deficiencies in the Post Sarbanes Oxley Era: The Role of Auditors and Corporate Governance', International Journal of Auditing 11, pp. 73-90.

26Ibid., note 25. 
Basically, another role carried out by the external auditors is stated in section 359 (1) of Companies and Allied Matters Act, ${ }^{27}$ which provides that the auditors of a company shall make a report to its members on the accounts examined by them, and on every balance sheet and profit and loss account, and all group financial statements copies of which are to be laid before the company in general meeting during the auditors' tenure of office. In the case of Sasea Finance Ltd. v KPMG,28 the court stated that the primary obligation for the auditor is, within a reasonable time, to exercise an appropriate level of skill and care in reporting to the company's members on the accounts of the company stating, in their opinion, whether the accounts of the company give a true and fair view of the company's financial affairs. KPMG has a duty to warn the company's directors as soon as the fraud or irregularities had been detected.

However, it should be clearly pointed out that it has been held in auditor's favour that it was not part of their duties to tell directors how to run the business and they had no power to insist that their recommended changes were put into operation. ${ }^{29} \mathrm{~A}$ learned author ${ }^{30}$ also added that the two main duties of an auditor includes to audit the accounts of the company and secondly to report to the members of the company on the account i.e. on every balance sheet and profit and loss account and all group account if any, laid before the company in general meeting during his tenure of office. The auditors' report must be open to inspection by any member. 31

An external auditor must act honestly, and with reasonable care and skill. He is liable to the company for loss resulting from his breach of duty. He may be liable in tort for negligent misstatements to the shareholder, debenture holder or investor if he knows that they intend to act on his statements. ${ }^{32}$ His duty is not confined to the machines of checking vouchers and making arithmetical computations. He should approach his job with an alert mind and if there is anything suspicious, he should probe it exhaustively. Thus, in Re Thomas Gerrard and Son Ltd,33the company's managing director falsified the company's books and invoices in a manner which would immediately raise suspicion. Believing him to be of the highest integrity, the auditors accepted his explanations of the alterations and certified the accounts. As a result, the company paid tax and dividends on inflated profits. The auditors were held liable. But in the absence of suspicious circumstances, an auditor is entitled to assume that the company's officers are honest and responsible and he may rely on their representations provided he is careful. ${ }^{34}$ In Re London and General Bank (No.2) ${ }^{35}$ the accounts contained in the face value of certain loans which the auditors knew were not realizable. He had pointed this out to the directors showing the gravity of the company's position, but his report to the shareholders merely stated that the value of the assets as shown on the balance sheet is dependent upon realization. As a result, dividends were paid out of capital. He was held liable for the amount of the dividends paid. In Re Thomas Gerrard and Sons Ltd, ${ }^{36}$ the court stated:

The auditors of a company owe a statutory duty to make to the members a report containing certain statements. If the directors do not allow auditors time to conduct such investigations as are necessary in order to make these statements, the auditors must, it seems to me, either refuse to make a report at all or make an appropriately qualified report. They cannot be justified in making a report containing a statement the truth of which they have not had an opportunity of ascertaining. ${ }^{37}$

It was also stated in this case that the standards of reasonable care and skill are more exacting today than those which prevailed in 1896 when Re Kingston Cotton Mill Co. (No. 2)38 was decided.

\section{The Place of Audit Committee in Corporate Governance}

The financial statement prepared by the board of directors shall also pass through the Audit Committee.39 The Audit committee plays a vital role in financial and operational control in the whole system of corporate governance by making recommendations to the board concerning the appointment and remuneration of external auditors, reviewing auditors evaluation of the system of internal control and accounting and consideration and making of recommendations on the conduct of any aspect of the company which should be brought to the notice of the board of directors among others..$^{40}$ According to section 359(4) of CAMA,41'the Audit Committee shall examine the auditor's report and make recommendations thereon to the

\footnotetext{
27Ibid., note 25 .

28 (2000) 1 All ER 676

${ }^{29}$ Re SP Catterson\& Sons (1937) 81 Acct LR.

${ }^{30}$ Keenan, D.,Smith \& Keenan’s Company Law for Students, $10^{\text {th }}$ edn, (Great Britani: Financial Times Pitman Publishing, 1996$)$ pp. $414-415$.

${ }^{31}$ Ibid, note 30.

${ }^{32}$ Hedley Byrne v Heller (1964) A.C. 465.

33 (1968) Ch. 455, Re City EquitableFire Insurance Co. Ltd. (1925) Ch. 407.

${ }^{34}$ Re Kingston Cotton Mill Co. (No. 2) (1896) 2 Ch. 279.

35Re Kingston Cotton Mill Co. (No. 2), supra,note 34.

${ }^{36}$ Re Kingston Cotton Mill Co. (No. 2), supra,note 34.

37Ibid, note 36, p. 477, per Penny Cuick, J.

${ }^{38}$ Supra; See also Gaius Ezejiofor, et al.,Nigerian Business Law, (London: Sweet \& Maxwell Limited, 1982) p. 317.

39This is after external auditor had audited the financial statement, the auditor is required to make report to audit committee in case of public company - see section 359(1)(3) of CAMA.

40Okeahalam, C.C. and Akinbode, O.A.op. cit. note 4, p.15.

${ }^{41}$ In Nigeria, the Corporate Audit Committee made its first appearance in the Companies and Allied Matters Act of 1990. It is to be composed of an equal number of the company's directors and representatives of the shareholders, subject to maximum number of six members. See section 359(3) of CAMA.
} 
annual general meeting as it may think fit.' And subject to such other additional functions and powers that the company's article of association may stipulate, the objectives and functions of audit committee shall be to:

- Ascertain whether the accounting and reporting policies of the company are in accordance with legal requirements and agreed ethical practices;

- $\quad$ Review the scope and planning of audit requirements;

- Review the findings on management matters in conjunction with the external auditor and departmental responses thereon;

- Keep under review the effectiveness of the company's system of accounting and internal control.

- Make recommendations to the board in regard to the appointment, removal and remuneration of the external auditors of the company; and

- Authorize the internal auditors to carry out investigations into any activities of the company which may be of interest or concern to the committee.42

The Audit Committee has been described as the most important development in corporate structure and control in decades. It is conceived as an investor's protection device. The origin of corporate audit committee is traceable to the celebrated fraud case involving Mc Kesson and Robin in the United State of America 1939. An enduring legacy of the case was the recommendation by the United State Securities and Exchange Commission in 1940 that every public company should establish an Audit Committee to strengthen its structure of corporate governance and accountability.43This recommendation was adopted by the 1990 Companies and Allied Matters Act in Nigeria and presently, the Audit Committee has been mandatorily compelled to be responsible for the review of the integrity of the bank's financial reporting and oversee the independence and objectivity of the external auditors. ${ }^{4}$

Corporate governance does not just work in isolation, it works through some mechanisms. The direction and control of corporate entities are statutorily regulated in Nigeria as in many other countries of the world through the following mechanisms: The board of directors, audit committees, Members at Annual General Meeting (AGM) and external auditors. ${ }^{45}$ However, only one of the mechanisms will be discussed in detail and that is audit committee. The Audit Committee has been described as the most important development in corporate structure and control in decades. ${ }^{46}$ It is however seen as an investor's protection device. Audit Committee is also an essential organ of corporate governance, particularly in public companies. Every public company should as a matter of necessity have Audit Committee. ${ }^{47}$

The audit committee is therefore a key governance structure charged with oversight over financial reporting and disclosure. Apart from the statutory Audit committee, as required (of public companies by the Companies and Allied Matters Act ${ }^{48}$ which is made up of an equal number of directors and shareholder representations, a company may also have a Board Audit committee. Indeed, the CBN code of corporate governance provides for the establishment of a Board Audit Committee made up of non-executive directors and chaired by an independent director. The statutory duties and role of the audit committee are clearly encapsulated in section 359 (3) and (4).49 In addition, the various codes of corporate governance - the CBN, SEC and NAICOM codes set out the corporate governance role \& responsibilities of the audit committee to include the following:

- Ascertain whether the accounting and reporting policies of the company are in accordance with legal requirements and agreed ethical practices,

- Review the scope and planning of audit requirements.

- Review the findings on management matters in conjunction with the external auditor and departmental responses thereon (management letter);

- Keep under review the effectiveness of the company's system of accounting and internal control;

- Make recommendations to the Board in regard to the appointment, removal and remuneration of the external auditors of the company, ensure the independence and objectivity of the external auditors and that there is no conflict of interest which could impair the independent judgment of the external auditors; and

- Authorize the internal auditor to carry out investigation into any activity of the company which may be of interest or concern to the committee.

- Assist the oversight of the integrity of the company financial statements and establish and develop the internal audit function.

\footnotetext{
${ }^{42}$ Companies and Allied Matters Act, op. cit., Section 359 (6)(a)-(f).

${ }^{43}$ Okpeahior, R. and Faga, H.P.op. cit., note 5, p.218.

${ }^{44}$ Otuwanuga, S.E., 'Shareholders' Activision - Role in Corporate Governance and Investor Protection', Law and Investment Journal, Vol. 1 No 2 (2007), p. 25.

45 Okpeahior, R. \& Faga, H.P., 'Reflection of Sound Corporate Governance for a Thriving National Economic Environment, Ebonyi State University Law Journal, Vol. 2 No. 1, (2007) p. 210-222, p. 215.

46 Berle, A.A. and Means, G.C.,The Modern Corporation and Private Property (New York: Macmillan, Nineteenth Printing, 1962) p. 13, cited in Okpeahior, R. and Faga, H.P.op. cit, note 5, p. 218).

47 Ogbuanya, N.C.S.,Essentials of Corporate Law Practice in Nigeria, (Nigeria: Novena Publishers Ltd, 2010) p. 453.

${ }^{48}$ CAMA, Cap.C20, LFN,2004.

49 Ibid.
} 
The Audit committee has a responsibility to ensure that the company's financials are void of any misrepresentation or misleading information. The committee may also play a significant role in the oversight of a company's risk management policies and programmers where there is no Board Risk Management Committee charged with this function. The role of the audit committee in corporate governance has evolved in the wake of the corporate governance failures around the world. Thus, the audit committee has become increasingly relevant in enhancing confidence in the integrity of an organizations processes and procedures relating to internal control and corporate and financial reporting. The Audit committee has become one of the main pillars of corporate governance in checkmating and forestalling corporate misconduct. The effectiveness of the audit committee determines to a large extent the integrity of a company's financials. To be effective therefore, the audit committee should have a charter that should clearly define its responsibilities and modus operandi and establish the right tone at the top. Members of the committee should possess basic financial literacy. Indeed, it is not out of place to designate a member as the financial expert; be able to commit time and effort to the task; ask the right questions of management, seek professional advice where necessary, recognise that the role is not merely ceremonial and above all, be men and women of integrity. ${ }^{50}$ Subject to the additional powers that may be stipulated and provided in the company's articles of association, the audit committee is to examine the auditor's report and make recommendations thereon to the Annual General Meeting as it may think fit. ${ }^{51}$ Most importantly, Section $359(6)^{52}$ generally sets out more particularly the objectives and functions of the committees. The objectives and functions of the audit committee shall be to-

- Ascertain whether the accounting and reporting policies of the company are in accordance with legal requirements and agreed ethical practices;

- $\quad$ Review the scope and planning of audit requirements;

- Review the findings on management matters in conjunction with the external auditor and departmental responses thereon;

- $\quad$ Keep under review the effectiveness of the company's system of accounting and internal controls;

- Make recommendations to the board in regard to the appointment, removal and remuneration of the external auditors of the company; and

- $\quad$ Authorize the internal auditor to carry out investigations into any activities of the company which may be of interest or concern to the committee.

It is pertinent to note that in the United Kingdom, for example, no statutory functions are imposed on the audit committees..$^{53}$ However, as postulated by a learned author ${ }^{54}$ on the duty of the audit committee, made up of non-executives, their function is to review the effectiveness of the company's auditing procedures and to liaise with the auditors. The Nigerian provisions set out the functions of the committee in details designed perhaps to solve the peculiar problems of the Nigerian corporate management.

The audit committee as already noted consists not of 'insiders' only but also 'outsiders' who can bring their respective ideas and independent minds to bear on the issues at hand. However, due care and diligence must be exercised and taken in other to ensure that the committee does not become forum for confrontation in the affairs of the company especially between the directors on the one hand and shareholders on the other. Rather, their effort should be geared towards ensuring that they work harmoniously to correct errors and implement and observe its functions duly accorded it.

\section{Impact of Auditing under the Rules of Corporate Governance}

Audit deals with the examination of the books of accounts of a company by external experts with a view to ascertaining its compliance with the accounting policy of the company and accounting standard rules. The audited account also shows the financial state of the company. Thus, audited account of a company constitutes the proof of the company's financial status. ${ }^{55}$ In the case of Livestock Feeds Plc v Igbino Farms Ltd, ${ }^{56}$ the court held that the audited statement of account of a company is the best way of showing the financial position of the company at any given time.

Auditing has been defined as the independent examination of the financial statements (together with the underlying books and records) of an organization, the purpose being to enable the auditor form an opinion on the basis of which to make a report that the financial statements, the subject of his examination, show a true and fair view. ${ }^{57}$

Corporate auditing is indeed an effective mechanism for providing assurance to the investors and other stakeholders that their interest secured. The principal characteristics of ensuring effective corporate governance such as transparency, accountability and integrity are enhanced with conduct of audit into the affairs of a company. Generally, internal and external auditors may conduct audit into the operation of a company. The internal auditors are the employees of a company who are appointed by the management to carry out audit of the day-to-day affairs of the company as part of the internal control

\footnotetext{
${ }^{50}$ Adeifemi, B., 'Role of Audit Committee as Corporate Governance Business Intelligence, September 23, 2013.

51 Companies and Allied Matters Act, op. cit, section 359.

52Ibid., note 51.

53 Orojo, O.J.,op. cit., p. 311.

54 Parkinson, J.E.,Corporate Power and Responsibility: Issues in the Theory of Company Law (New York: Oxford University Press Inc., 1993 ) p. 58.

55 Ogbuanya, N.S.C.,Essentials of Corporate Law Practice in Nigeria (Novena Publishers Ltd, (Best Practice Books Series) Nigeria 2010 ) p. 444.

56 (2002) 5 NWLR (Pt.759) 118-134.

${ }^{57}$ Aguolu, O.,Fundamentals of Auditing, 3rdedn., (Institute for Development Studies, Nigeria, 2008) p. 560.
} 
system. The external auditor on the other hand, is highly regarded in the corporate governance framework because unlike the internal auditor, he is appointed by the shareholders. The external auditor is an independent person or firm of auditors appointed according to statutory requirement to investigate the financial statements of an entity and express his opinion in form of report on the true and fair view of such financial statement.58

Auditing standards ensures that the basic rules of corporate governance such as objectivity, integrity, accountability, etc. which are essentially in the auditors' performance of his responsibilities are highly actualized. These basic rules of governance, when it is fully observed with implementation, make good corporate governance to thrive. It is, however, auditing process that can impact positively in the concerned company in achieving these goals. So, a good auditing is very crucial in the rules of corporate governance. Auditing can impact the risk-taking incentives of management through an appropriate application of accounting policies. However, it is also important to ensure that rules (in the event of a breach of accounting policies) are correspondingly enforced. Another effect auditing has impacted positively in a company is corporate accounting scandal. Under this case, there must be a fair and true auditing, if not, corporate accounting scandal can surface and at the end leaves the company no choice than going bankrupt.

The frequency of corporate scandal in the past decades is alarming and has caused the public to question what the role and impacts that auditors have in corporate governance. The numerous cases of corporate accounting scandal have created crisis of confidence in the accountancy profession though not every case of corporate scandal and failure can be attributed to auditing failure or auditor's negligence. Some of the high-profile cases of such corporate scandals are Enron, WorldCom, Parmalat, etc.59Auditing has established an enhanced corporate accountability by working with the board of directors and management to improve control and strengthen the financial reporting practices of a company. The goal has been to promote proper conduct of the affairs of the corporation in line with generally accepted accounting, ethical and legal standards. That being the case, the achievement of these objectives provides protection for the shareholders especially their respective interest.

Auditing ensures checks and balances on the board of directors and management. It is very important to bear on companies the political doctrine of separation of power. That power corrupts and absolute power corrupts absolutely, is a well-known adage. To saddle the chairman of a company with the additional duty of chief executive is to make him accountable to himself as he presides over both the board and management and without much power on any other person to question his action or inaction. Same thing applies to the directors that prepare the financial statement of a company.

It is however, auditing that would act as cheek on them and as well the auditors will in turn be accountable and answerable, to the members in general meeting. When this auditing process is there, the directors and the management will be moved to be diligent and careful in performing and carrying out their respective duties without any symptom of negligence on their part.

Another impact of auditing under the rules of corporate governance is publication of credible and reliable information about the subject matter concerned especially to the members. The auditor has done or contributed much in the nation. The credible and reliable information, especially financial statements published, avails the members wherever they are to reasonably determine whether the company they are investing in is worth it. This is because even the company's profit and loss account are also contained in the report. It then leaves the member the choice to decide whether to continue investing in such a company or to decline. The auditing process also is a cheek whether the financial information given to investors is reliable or not. Auditing process has gone very far in establishing confidence and trust on the company which in turn has reduced uncertainty and risk thereby adding value. If there is confidence and trust among the members in a company it will be a motivating factor that increases their investment in the company thereby enhancing profits.

The efficacy of the accounting system in reducing agency conflicts depends, at least in part, on whether accounting principles are applied in a manner consistent with Generally Accepted Accounting Principles (GAAP), or other standards outlined in the contracting setting. The auditor has served as a central effort beyond it. That is, in order for accounting reports to be effective in reducing agency costs, contracting parties must be provided with some assurance that the financial reports have been prepared in accordance with the provisions of the contract. This gives rise to a demand for auditing, as an audit certification provides some assurance that the financial statements have been prepared in accordance with a set of recognized principles. This assurance can come from either the insurance role of the audit (i.e., the auditor can be sued if there is an error or irregularity), or from the auditor's reputation. When financial accounting numbers play a more prominent role in the contract, the demand for auditing is expected to be greater.

It is widely acknowledged that the impact of auditing is very alarming. There is no doubt that auditing has brought about improvement in accountability and transparency in corporate governance thereby reducing the company's death or bankruptcy.

\footnotetext{
${ }^{58}$ Alabede, J.O., The Role, Compromise and Problems of the External Auditor in Corporate Governance', Research Journal of Finance and Accounting, vol. 3 No 9 (2012), p.155, available at URL www.iiste.org, accessed on 21/ 09/ 2013). 59Ibid, et el, p. 119.
} 


\section{The Independence of Auditors as a Necessary Condition for Effective Governance}

Independence of the auditor is a very vital underlying tool for every audit engagement for good and effective corporate governance. The auditor must be independent of his mind devoid of any kind of inhibitions especially from the board or management in performing his duties and functions. He should be free to reason the way that he thinks to be the best practice and as well free to evaluate the financial statements the way he chooses to be professional. In this case, accounting scandal and collapse of company can be highly avoided, and on the contrary will lead to winding up of the company. Accordingly, a learned author, ${ }^{60}$ in his book stated:

Both in statutory audit and private audit engagements, the auditor is expected to exercise independence in the performance of his job. This is necessary for him to give an objective and unbiased report. For all statutory audits, the auditor is considered to be independent. Practically however, it is impossible for the auditor to be absolutely independent as envisaged in the act, since he needs to maintain a constructive and proactive working relationship with the directors who actually pay his fee. Nonetheless, the independence of the auditor is very important for any successful audit. The independence of the auditor is not just a matter of fact. It is also a matter of the attitude of his mind. By his conduct, he must be truly independent. To ensure the independence of the auditor, the law grants him substantial rights and protection. ${ }^{61}$

The faith of the stakeholders in the auditor's report is rooted in the fact that auditor is free from the influence of management, that is independent of management. Independence of the auditor is central to audit. The report of auditor who is not seen to be independent may be regarded as unreliable and lacking credibility. Auditors are expected to be independent of the company and report on the company objectively. Actually, auditors can only play their role effectively if they are independent. This is based on the fact that they have to conduct their tasks in the most independent and reliable manner to provide investing public with the level of much assurance to make their decisions based on financial statements.

Auditor independence therefore refers to the independence of the internal auditor or of the external auditor from parties that may have a financial interest in the business audited. ${ }^{62}$ Independence requires integrity and an objective approach to the audit process. The concept requires the auditor to carry out his or her work freely and in an objective manner. In addition to a clear understanding of the independence of auditors, independence of internal auditors means independence from parties whose interests might be harmed by the results of an audit. Specific internal management issues are inadequate risk management, inadequate internal controls, and poor governance.63 Independence of the external auditor, on the other hand, means independence from parties that have an interest in the results published in financial statement of an entity. Auditor independence is commonly referred to as the cornerstone of the auditing profession since it is the foundation of the public's trust in the accounting profession. ${ }^{6}$

On the other hand, Black's Law Dictionary, 65 defined independent audit as an audit conducted by an outside person or firm not connected with the person or organization being audited. It also defined internal audit to mean an audit performed by an organization's personnel to ensure that internal procedures, operations, and accounting practices are in proper order.

Auditors' independence may be threatened by factors such as deriving significant financial interest from a client, provision of non-audit services to a client, having close relationship with a client and intimidation.66 In recent times, it was reported that the greatest threat to the auditor's independence is the provision of non-audit services to clients. ${ }^{67}$ Auditors may compromise their independence because they derived substantially part of their income from non-audit services. Evidence has shown that the large firms derive great part of their income from non-audit services. The problem with provision of non-audit services is that it divides the focus of the auditor and creates unnecessary compromise. 68

Another area of independence, which not much is talked about, is appointment of external auditors, which in theory is done by the shareholders ${ }^{69}$ from recommendations of the directors. In reality, the management does the appointment and auditor may do anything to favour his employer. ${ }^{70}$ Safeguards which exist to ensure that threats to auditor's independence are mitigated include: prohibitions, restrictions, policies, procedures and the requirement for disclosures. Notwithstanding the above mitigating factors, the Cadbury's Report ${ }^{71}$ stated that the auditor's independence could be affected due to the close relationship between auditors and company managers and due to the auditor's intention to develop a constructive relationship with their clients. There are a number of threats to providing non-audit services since non-audit services are lucrative. Auditors can obtain the contracts for non-audit services only if they maintain a good relationship with the management.

\footnotetext{
${ }^{60}$ Aguolu, O.,Fundamentals of Auditing, op. cit, note 57, p.10.

61 Ibid, note 60, p.12.

${ }^{62}$ Available at: http:/ / on.m.wikipedia.org/ wiki/ wuditor-indepndence, accessed on 11/ 03/ 2018.

63Ibid., note 62.

${ }^{64}$ Ibid. note 62.

65 Garner, B.A.,Black's Law Dictionary, 7thedn, (West Group, St. Paul, Minn., 1999) p. 126.

${ }^{66}$ Alabede, J.O., The Role, Compromise and Problems of the External Auditor in Corporate Governance', op.cit, note 58, p. 120.

67Ibid., note 66 .

${ }^{68} \mathrm{Ibid} .$, note 66.

${ }^{69}$ Companies and Allied Matters Act, Cap. C20, LFN, 2004, section.357(1).

70Ibid., note 69

${ }^{71}$ Report of the Committee on the Financial Aspect of Corporate Governance (1992).
} 
Lack of auditor independence has resulted to corporate accounting scandal and collapse of companies. ${ }^{72}$ When there is auditor's independence, it will be difficult to raise the defence that it is clients' responsibility to detect and prevent fraud, error and other irregularities in their company. This is due to the fact that the auditors are still seen as the watchdog that detects when and when not, the company is suffering from any ill health or embarking on any unprofitable transaction. However, on the account of auditor's relationship with their client, in May 2002 the Commission ${ }^{73 i s s u e d ~ a ~ r e c o m m e n d a t i o n ~ o n ~ t h e ~}$ independence of statutory auditors. A recommendation is not legally binding on member states but it is a statement of good practice which the member states are expected to take into account. The key element of the Recommendation is that auditors should be prohibited by law from carrying out a statutory audit if they have any relationship with their client (meaning any financial, business, employment or other link including the provision of non-audit services) that might jeopardize their independence.

As earlier noted, auditor's independence refers to the independence of the internal auditor or of the external auditor from parties that may have a financial interest in the business being audited. Independence requires integrity and an objective approach to the audit process. The concept requires the auditor to carry out his or her work freely and in an objective manner. An independent auditor is a certified public accountant who examines the financial records and business transaction of a company that he/ she is not affected with. As it is, an independent auditor is typically used to avoid conflicts of interest and to ensure the integrity of the auditing process. In other words, independent auditors are often used-or even mandated to protect shareholders and potential investors from the occasional fraudulent or unrepresentative financial claims made by public companies.

Auditor's independence is commonly referred to as the cornerstone of the auditing profession since it is the foundation of the public's trust in the accounting profession. ${ }^{74}$ Since 2000, a wave of high profile accounting scandals has cast the profession into the limelight, negatively affecting the public perception of auditor independence.The charter of audit and the reporting to an audit committee of the company (and of the internal audit profession) helps to give guidance and independence from suppliers, clients, third parties etc. The support from and in relation to the Audit committee of the client company, the contract and the contractual reference to public accounting standards/ codes generally provides independence from management.

The auditor should, as a matter of necessity, be independent from the client company. The auditors are expected to give an unbiased and honest professional opinion on the financial statements to the shareholders. Doubts are sometimes expressed regarding the independence of external auditors. It can be argued that unless suitable corporate governance measures are in place, a firm of auditors may reach audit opinions and judgments that are heavily influenced by the wish to maintain good relations with the client company. If this happens, the auditors can no longer be said to be independent and the shareholders cannot rely on their opinion. Further, accounting firms sometimes engage and set auditor fees at less than the market rate and make up for the deficit by providing non-audit services such as management consultancy and tax advice. As a result, some audit firms have commercial interest to protect too. This raises concerns that the auditor's interests to protect shareholders of a company and his commercial interests may conflict with each other. ${ }^{75}$ It could be rightly said that auditor independence is important given the numerous advantages enjoyed in such practice. Its importance includes:

- Provision of Reliable Financial Information: Shareholders and other stakeholders need a trustworthy record of director's stewardship to be able to take decision about company. More so, assurance provided by auditors is a key quality control on the reliability of information.

- The provision of credible financial information: Unqualified report by independent external auditors on the account should give credibility and enhance the appeal of the company to investors. This unqualified report should represent the views of independent expert who are not motivated by personal interests to give a favourable opinion.

\footnotetext{
${ }^{72}$ Alabede, J.O.op cit., note 58, p. 119. Note for instance, Enron accounting scandal was a popular one. Enron was established in 1985 as US based energy company and it was prosperous in its early life that its stock increased by about $311 \%$ in the $1990_{s}$. Though the sign of distress in the company started emerging in 1997 when it wrote off $\$ 537$ million to settle a contract dispute with another company, it became obvious that Enron was in serious problem when in November, 2001 it restated its account of 1997-2000 to correct accounting abnormality. The restatement brought down its reported earnings for this period by $\$ 591$ million. Consequently, the credit rating agents downgraded the company and it filed for bankruptcy in December 2001 . Arthur Andersen who was the auditor of Enron was accused of negligence in its duty and was criticized of compromising its professional position for financial gain and this led to the winding up of the firm..$^{72}$ Another incidence of accounting scandal is the case of WorldCom which is also another high-profile accounting scandal resulting from audit failure. WorldCom was US based telecommunication company, which grew rapidly through aggressive acquisition. In 2002, the internal auditors of the company uncovered $\$ 3.8$ billion fraud perpetrated by inflating the revenue and treating revenue expenses as capital expense. This resulted into $\$ 3.3$ billion not properly accounted for between 1999 and first quarter of 2002. Arthur Anderson who was the auditor of the company issued a clean health report on the company during the period and did not uncover the fraud.

73 European Commission Recommendation of 16 May 2002 - Statutory Auditors' Independence in the European Union: A Set of Fundamental Principles', OJL 191, 19. 07. 2002, p. 22, cited in Hannigan, B.,Company Law, (Lexis Nexis, Butterworths, UK, 2013) p. 51.

74 Lindbery, D.L. \& Beck, F.D., 'Before and After Enron: CPAs View on Auditor Independence, The CPA Journal online, 2004

75 A trite profile example would be the relationship between Enron and their auditor,Arthur Andddersen. In 2000, Andersen received \& s17m for non-audit services, compared with \& $25 \mathrm{~m}$ for anti-services. Meaning Enorn accounted for over 25\% of the fees general by the firms Houston office. In the after math of Enorn's demise, the accounting firmswas accused of not acting independently and suggestions were made that they had gone along with the accounting practices in Enron in order to retain their work.
} 
- Value for Money of Auditor Work: A lack of independence seems to mean that important auditor's work may not be done, and thus, shareholders are not receiving value for the audit fees.

- Threats to Professional Standards: A lack of independence may lead to a failure to form the basis of an audit opinion, in this case, to obtain details of a questionable material item, and failure by auditors to do this undermines the credibility of the accountancy profession and the standards it enforces.

The audit profession has however, recognized the following threats to auditor independence, many of which are linked to the provision of non-audit services:

- $\quad$ Self-interest threats: This involves where an auditor is financially dependent on the audit client or where an auditor or someone closely associated with him has a financial or other interest in the audit client; and the auditor also depends on the management of the company to secure its reappointment as auditor.

- Familiarity threats: The relationship between the auditor and client could be long-standing or otherwise is so familiar that the auditor becomes involved in advising the client or acting in a management role.

- Self-Review Threats: A judgment is required of the auditor which demands that previous work of the firm (whether audit or non-audit) be challenged or re-evaluated.

- The Trust Threats: The auditor becomes too trusting of directors and management, thereby preventing a proper testing of management information and representations.

- The Intimidation Threats: The auditor is intimidated by actual or potential pressures from the client or other party.

- The Advocacy Threats: The auditor becomes involved in actively promoting or defending the client's interests.

The need for independence arises because in many cases users of financial statement and other third parties do not have sufficient information or knowledge to understand what is contained in a company's annual accounts. Thus, they rely on the auditor's independent assessment. Public confidence in financial markets and the conduct of public interest entities rely partly on the credibility of the opinions and reports given by auditors in relation with financial audits.

\section{Conclusion and Recommendation}

Good corporate governance by board of directors is recognised to have great influence on the quality of financial reporting which in turn has an important impact on investor confidence. The search for mechanisms to ensure reliable, high quality financial reporting has largely focused on the structure of audit quality. Therefore, financial reporting and auditing were all designed to provide protection to investors. This is being achieved by imposing a duty of accountability upon the managers of a company. In essence, auditing is used to provide the needed assurance for investors when relying on audited financial statements. However, it was found that despite the strict application of the rules of auditing, they can hardly offer adequate protection against errors, collusion and deceit. Accordingly, there is façade of corporate auditing as shareholders merely rubber stamp the financial statements, assuming that having gone through internal audit controls, the financial statements ought to be in order. It was further found that no matter how strict and consistent the rules of auditing are applied, it can hardly afford perfect protection against human factors such as susceptibility to errors, collusion and deceit. It is therefore recommended that the powers of regulatory agencies should be strengthened to ensure that auditors properly scrutinize the financial statement of the enterprise. Despite the power given to the shareholder to consider and approve the appointment and remuneration of auditors as well as the financial statement in a general meeting so as to ensure that the board of directors observes financial discipline in the management of the company, the shareholders have not efficiently utilized the power. Auditor ensures that the inaccuracies and deficiencies associated or perpetrated in the internal control system of the company is under control, and that the external auditors role will go a very long way to curtail these problems. This is in order to restore trust and public confidence in the company and as well remove the probability of the company going bankrupt. And through the role performed by the external auditors, the shareholders monitor and control the management, and this in return will help to enhance transparency and accountability in the company.

\section{References}

i. Section 279 of CAMA provides that a director of a company stands in a fiduciary relationship towards the company.

ii. Companies and Allied Matters Act (CAMA), Cap. C20, Laws of the Federation of Nigeria 2004, S.357.

iii. Companies and Allied Matters Act, op. cit, S.360 (5).

iv. Okeahalam, C.C. and Akinbode, O.A., 'A Review of Corporate, Governance in Africa: Literature, Issues and Challenges', a Paper Prepared for the Global Corporate Governance Forum, 15 June, 2003.

v. Okpeahior, R. and Faga, H.P. 'Reflection on Sound Corporate Governance for a Thriving National Economic Environment', Ebonyi State University Law Journal, Vol.2, No 1, (2007) p. 218.

vi. Okeahalam, C.C. and Akinbode, O.A. op. cit, note 4, p.15.

vii. See generally section. 357 of CAMA particularly, subsection 3 of same section which provides that where at an annual general meeting, no auditors are appointed or re-appointed, the directors may appoint a person to fill the vacancy.

viii. Opeahior, R. and Faga, H.P. op. cit, note 5, p.218.

ix. Escrow is a bond, deed, or other document kept in the custody of a third party and taking effect only when a specified condition has been fulfilled. 
x. Cap. C20 LFN, 2004.

xi. Asein, A.A., 'Managing Audit Risks', The Nigerian Accountant, Vol. 32 No 1 (January and March, 1999) (Cited in Okpeahior, R. \& Faga, H.P., op. cit, note 5, p. 1.

xii. Companies and Allied Matters Act, op. cit, section 357.

xiii. Onwuoduoki, E.A., 'Current World Financial Crisis: Lessons to be Learnt, in O. Alo (ed), Issues in Corporate Governance, (2003) p. 51, cited in Okpeahior, R. \& Faga, H.P., op. cit, note 5, pp. 217-218.Ibid., note 13.

xiv. Cap. B3, LFN, 2004.

xv. Banks and Other Financial Institutions Act, Cap. B3, LFN, 2004, S. 29.

xvi. Alabede, K.O., The Role, Compromise and Problems of the External Auditor in Corporate Governance', Research Journal of Finance and Accounting, Vol. 3 No 9 (2012) p. 115,available at: URL www.iiste.org, accessed on 21/ 09/13; Aguolu, O., Fundamentals of Auditing, 3rd edn, (Institute for Development Studies, Nigeria, 2008) p. 7. Ibid.

xvii. 19. Cap. C20 LFN, 2004; See also the equivalent provisions in the United Kingdom Companies Act 2006, particularly sections 495-498. (1887) 36 Ch. D 787.

xviii. (1911) 44 Acct LR 25, See also Re City Equitable Fire Insurance Co. Ltd (1924) 71 Acct LR 81. (1992) 10 ACLC 933.

xix. Available at: http:// www.eh ow.com/ list-6582612-external-auditor-s-duries-html., accessed on 24/ 03/ 2018(1895) 2 Ch. 673

xx. Krishaman, G.V. and Visvanathan, G., 'Reporting Internal Control Deficiencies in the Post Sarbanes Oxley Era: the Role of Auditors and Corporate Governance', International Journal of Auditing 11, pp. 73-90. Ibid., note 25.Ibid., note 25. (2000) 1 All ER 676.Re SP Catterson \& Sons (1937) 81 Acct LR.

xxi. Keenan, D., Smith \& Keenan's Company Law for Students, 10thedn, (Great Britani: Financial Times Pitman Publishing, 1996) pp. 414-415. Ibid, note 30.

xxii. Hedley Byrne v Heller (1964) A.C. 465.(1968) Ch. 455, Re City EquitableFire Insurance Co. Ltd. (1925) Ch. 407.

xxiii. Re Kingston Cotton Mill Co. (No. 2) (1896) 2 Ch. 279.

xxiv. . Re Kingston Cotton Mill Co. (No. 2), supra, note 34.

xxv. Re Kingston Cotton Mill Co. (No. 2), supra, note 34.

xxvi. Ibid, note 36, p. 477, per Penny Cuick, J.

xxvii. Supra;See also Gaius Ezejiofor, et al., Nigerian Business Law, (London: Sweet \& Maxwell Limited, 1982) p. 317.

xxviii. This is after external auditor had audited the financial statement, the auditor is required to make report to audit committee in case of public company - see section 359(1)(3) of CAMA.

xxix. Okeahalam, C.C. and Akinbode, O.A. op. cit. note 4, p.15.

xxx. In Nigeria, the Corporate Audit Committee made its first appearance in the Companies and Allied Matters Act of 1990. It is to be composed of an equal number of the company's directors and representatives of the shareholders, subject to maximum number of six members. See section 359(3) of CAMA.

xxxi. Companies and Allied Matters Act, op. cit., Section 359 (6)(a)-(f).

xxxii. Okpeahior, R. and Faga, H.P. op. cit., note 5, p.218.

xxxiii. Otuwanuga, S.E., 'Shareholders' Activision - Role in Corporate Governance and Investor Protection', Law and Investment Journal, Vol. 1 No 2 (2007), p. 25.

xxxiv. Okpeahior, R. \& Faga, H.P., 'Reflection of Sound Corporate Governance for a Thriving National Economic Environment, Ebonyi State University Law Journal, Vol. 2 No. 1, (2007) p. 210-222, p. 215.

xxxv. Berle, A.A. and Means, G.C., The Modern Corporation and Private Property (New York: Macmillan, Nineteenth Printing, 1962) p. 13, cited in Okpeahior, R. and Faga, H.P. op. cit, note 5, p. 218).

xxxvi. Ogbuanya, N.C.S., Essentials of Corporate Law Practice in Nigeria, (Nigeria: Novena Publishers Ltd, 2010) p. 453.

xxxvii. CAMA, Cap.C20, LFN, 2004. Ibid.

xxxviii. Adeifemi, B., 'Role of Audit Committee as Corporate Governance Business Intelligence, September 23, 2013.

xxxix. Companies and Allied Matters Act, op. cit, section 359.Ibid., note 51.

xl. Orojo, O.J., op. cit., p. 311. Parkinson, J.E., Corporate Power and Responsibility: Issues in the Theory of Company Law (New York: Oxford University Press Inc., 1993) p. 58.

xli. Ogbuanya, N.S.C., Essentials of Corporate Law Practice in Nigeria (Novena Publishers Ltd, (Best Practice Books Series) Nigeria 2010) p. 444.

xlii. (2002) 5 NWLR (Pt.759) 118-134.

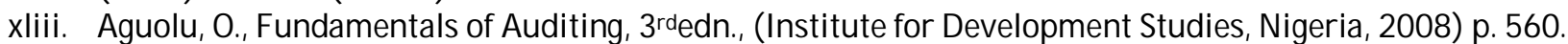

xliv. Alabede, J.O., The Role, Compromise and Problems of the External Auditor in Corporate Governance', Research Journal of Finance and Accounting, vol. 3 No 9 (2012), p.155, available at URL www.iiste.org, accessed on 21/ 09/ 2013).

xlv. Ibid, et el, p. 119.Aguolu, O., Fundamentals of Auditing, op. cit, note 57, p.10.

xlvi. Ibid, note 60, p.12.Available at: http:/ / on.m.wikipedia.org/ wiki/ wuditor-indepndence, accessed on 11/ $03 / 2018$.

xlvii. Ibid., note 62. Ibid. note 62 .

xlviii. Garner, B.A., Black's Law Dictionary, 7thedn, (West Group, St. Paul, Minn., 1999) p. 126. 
xlix. Alabede, J.O., The Role, Compromise and Problems of the External Auditor in Corporate Governance', op.cit, note 58, p. 120.

l. Ibid., note 66. Ibid., note 66 .

li. Companies and Allied Matters Act, Cap. C20, LFN, 2004, section.357(1).

lii. Ibid. note 69. Report of the Committee on the Financial Aspect of Corporate Governance (1992).

liii. Alabede, J.O. op cit., note 58, p. 119. Note for instance, Enron accounting scandal was a popular one. Enron was established in 1985 as US based energy company and it was prosperous in its early life that its stock increased by about $311 \%$ in the 1990s. Though the sign of distress in the company started emerging in 1997 when it wrote off $\$ 537$ million to settle a contract dispute with another company, it became obvious that Enron was in serious problem when in November, 2001 it restated its account of 1997-2000 to correct accounting abnormality. The restatement brought down its reported earnings for this period by $\$ 591$ million. Consequently, the credit rating agents downgraded the company and it filed for bankruptcy in December 2001. Arthur Andersen who was the auditor of Enron was accused of negligence in its duty and was criticized of compromising its professional position for financial gain and this led to the winding up of the firm. Another incidence of accounting scandal is the case of WorldCom which is also another high profile accounting scandal resulting from audit failure. WorldCom was US based telecommunication company, which grew rapidly through aggressive acquisition. In 2002, the internal auditors of the company uncovered $\$ 3.8$ billion fraud perpetrated by inflating the revenue and treating revenue expenses as capital expense. This resulted into $\$ 3.3$ billion not properly accounted for between 1999 and first quarter of 2002. Arthur Anderson who was the auditor of the company issued a clean health report on the company during the period and did not uncover the fraud.

liv. European Commission Recommendation of 16 May 2002 - Statutory Auditors' Independence in the European Union: A Set of Fundamental Principles', OJL 191, 19. 07. 2002, p. 22, cited in Hannigan, B., Company Law, (Lexis Nexis, Butter worths, UK, 2013) p. 51.

lv. Lindbery, D.L. \& Beck, F.D., 'Before and After Enron: CPAs View on Auditor Independence,'The CPA Journal online, 2004

lvi. A trite profile example would be the relationship between Enron and their auditor, Arthur Andddersen. In 2000, Andersen received \& s17m for non-audit services, compared with \& 25m for anti services. Meaning Enorn accounted for over $25 \%$ of the fees general by the firms Houston office. In the after math of Enorn's demise, the accounting firms was accused of not acting independently and suggestions were made that they had gone along with the accounting practices in Enron in order to retain their work. 